JAN SAMEK

\title{
PROBLEMY OCHRONY ZABYTKÓW KOŚCIELNYCH W CZASACH TZW. REALNEGO SOCJALIZMU
}

Impulsem do podjecia niniejszej pracy, poza interesującym tematem sesji byl fakt, że jako student Uniwersytetu Jagiellońskiego na kierunku historii sztuki w latach od jesieni 1951 roku do zimy 1954 roku pracowałem w Wojewódzkim Urzędzie Konserwatorskim w Krakowie.

W tekście tym opieram się zarówno na publikacjach, w tym własnych, notatkach, fotografiach, jak i na wspomnieniach.

Chociaż na Uniwersytecie byliśmy zobowiazzani do uczestniczenia w 40 godzinach zajęć tygodniowo, praca w Urzędzie nie miała charakteru dorywczej. Obejmowała ryczał towo 100 godzin miesięcznie, z wynagrodzeniem (co można ze względów anegdotycznych podać), 450 a potem 600 zlotych. Do moich obowiązków należała opieka nad archiwum fotograficznym, zbieranie materialów i wykonywanie dokumentacji naukowych a także wizje lokalne w Krakowie i wyjazdy interwencyjne $w$ teren. Posiadalem pelny wgląd w prace Urzędu, bowiem stosunki między pracownikami, jak i między konserwatorem wojewódzkim byly niemal rodzinne.

Urząd Konserwatorski był częścia Wydzialu Kultury Wojewódzkiej Rady Narodowej w Krakowie. Tutaj należy wyjaśnić, że już 20 marca 1950 roku Ministerstwo Kultury i Sztuki utworzylo Urzad Miejskiego Konserwatora Zabytków, który rozpoczął dzialalność 1 listopada 1952 roku. Stosunki między obydwoma urzędami nie układały się dobrze, ponieważ Urząd Wojewódzki był m.in. silniej nastawiony na ochronę XIX-wiecznych zabytków.

Biura konserwatora mieściły się w dużej sali przy ulicy Basztowej, na I piçtrze, nad obecnymi pomieszczeniami LOT-u. Pracowników było niewielu. Funkcje konserwatora zabytków pelniła wtedy dr Hanna Pieńkowska. Objęła 
ten Urząd po profesorze Józcfie Edwardzie Dutkiewiczu, który odszedl do Akademii Sztuk Pięknych. Jej zastẹpcą byla mgr Aleksandra Wanicka (obecnie Kietlińska), a podpore Urzędu stanowili mgr Piotr Krakowski (obecnie profesor Uniwersytetu Jagiellońskiego) architekt i historyk sztuki, oraz prawnik i historyk sztuki z zamilowania mgr Marian Kornecki. Zatrudniano też dwie osoby $w$ administracji oraz - doraźnie - dodatkowych pracowników.

Dysponowaliśmy sporym archiwum z czasów przedwojennych, gdy funkcję konserwatora pelnił inż. Bogdan Treter. Bylo to archiwum stale wzbogacane przez notatki, plany i fotografie, które wykonywał wówczas Tadeusz Chrzanowski, obecnie emerytowany profesor Katolickiego Uniwersytetu Lubelskiego. Dysponowaliśmy też sporą biblioteką fachową i, co mialo istotne znaczenie, dostępną dla wszystkich pracowników ciemnię fotograficzną. Żaden ze stałych pracowników nie należał do partii, natomiast kierownicy wydziałów byli nastawieni prorzadowo (za moich czasów panowie Bieszczanin - malarz, i Woszczenko). Ten ostatni natarczywie nalegal na pracowników, aby zapisali się do partii, oczywiście bezskutecznie. Osoby otwarcie gloszące swoje poglądy, np. religijne, i jak czasowo zatrudniona $w$ Urzędzie moja małżonka, obecnie dr Izabella Rejduch-Samkowa musialy odejść z pracy.

W okresie gdy podjąłem tę prace będąc na Il roku studiów, zwiększyla się baza naukowa Urzędu Konserwatorskiego. Zaczęly ukazywać się poszczególne zeszyty Katalogu Zabytków wojewódzkiego krakowskiego pod redakcja profesora Szabłowskiego. Dawało to możliwość dobrej orientacji $w$ terenie i zachęcalo do stałej penetracji zabytków $w$ poszukiwaniu dziel architektury, malarstwa i rzemiosła artystycznego, których nie uwzgiędniono w Katalogu. W tym miejscu $z$ perspektywy czasu chcialbym stwierdzić, że w tym ciężkim okresie cechował wszystkich zapał i ofiarność, o która trudno byłoby dzisiaj.

Jakie byly glówne problemy inwentaryzacji? Nie stanowiły ich w owych latach zabytki kościelne. Najwięcej trudności sprawiały nam zajęte przez chlopów i Państwowe Gospodarstwa Rolne zabytkowe palacyki i dwory. Obiekty te dewastowano, zabytki znikaly z powierzchni ziemi zanim zostawaly zinwentaryzowane i sfotografowane. Wtedy, niestety, obowiazywała zaaprobowana przez profesora Jana Szabłowskiego granica 100 lat do np. 1850 roku, która decydowała o tym czy dany obiekt uznawano za zabytkowy, czy nie. W pracy jednak, kicrujac się wyczuciem, nie braliśmy jej pod uwagę. Istnial też z okresu sprzed II wojny światowej proceder uznawania dzieł sztuki za zabytki, co ze względów prawnych było bardzo pracochłonne. Ważna czynnością było także, choć zajmowała się tym tylko jedna osoba, wydawanie zezwoleń na wywóz obiektów za granicę. Wywożono, przynajmniej oficjalnie zabytki o świeckim przeznaczeniu, przy czym uwzględniano wykaz wybitnych artystów, głównie malarzy z bliższych nam czasów, których obrazów nie wolno było wywozić. 
Na czym więc ogniskowala się nasza praca w odniesieniu do obiektów sakralnych? Nie istnial jeszcze $w$ tym czasie problem wznoszenia licznych nowych kościolów, co lączylo się z przenoszeniem zabytków i pogarszaniem stanu dawnych budowli, ale oczywiście wykonywano w kościolach remonty, drobne prace budowlane, miały też miejsce dość liczne odkrycia.

Warto podkreślić, że pracownicy Urzędu Konserwatorskiego pozytywnie odnosili się do zabytków kościelnych. Oczywiście wszyscy wiedzieliśmy, że stosunek wladz do sztuki kościelnej nie promowal jej, ale wobec niskiego poziomu wiedzy wyższych urzędników na szczeblu wojewódzkim oraz faktu, że najwyższe władze w slużbie konserwatorskiej sprawowali fachowcy, latwo bylo obejść "socjalistyczny" stosunek wladzy do sztuki sakralnej. Wystarczalo umieścić zamiast hasła „kościól” opis typu: „konserwacja drewnianej architektury malomiasteczkowej i wiejskiej", a gdy chodzilo o obraz religijny podawaliśmy - "konserwacja dziela plastyki", natomiast gdy odnawialiśmy ornaty nazwę przedmiotu braliśmy n.p. z obrządku unickiego, a ta była dla urzędników całkiem nieznana.

Ale były i akcje bardzo brutalne w odniesieniu do zabytków ze strony władz komunistycznych - na przykład w czasowej likwidacji klasztoru benedyktynek iw Staniątkach.

Jakie ważne prace $z$ zakresu architektury sakralnej zostały wykonane przy użyciu funduszy konserwatora, a także środków jakimi dysponowała parafia?

Otóż jak zawsze podejmowane byly wspomniane prace remontowo-budowlane. Projektowano też nowe polichromie do kościolów, co wymagało badań. Każda nowa dekoracja w kościele, jeśli był zabytkowy musiała być zatwierdzana przez konserwatora. Bardzo pożyteczna byla wspólpraca z Katedra Konserwacji Malowidel Ściennych Wydzialu Konserwacji Akademii Sztuk Pięknych w Krakowie, gdzie czynny był profesor Edward Dutkiewicz. Według artykułu Hanny Pieńkowskiej, zamieszczonego w "Wiadomościach Konserwatorskich”, zatytulowanego „Ważniejsze badania odkrywkowe i odkrycia malowidel ściennych w województwie krakowskim w latach 19511958", przeprowadzono badania w Prandocinie, Wysocicach, Dziekanowicach, Rożnowie, Niepolomicach, Tyńcu, Siemiechowie, Nowym Sączu, (kościół i klasztor ponorbertański), Gnojniku, Kościelcu, Modlnicy, Podolu, Raciborowicach, Racławicach Olkuskich, Ruszczy, w miejscowościach Rzyki, Sucha, Tropie, Wawrzeńczyce, Wieloglowy, Zator, Zbylitowska Góra, Żębocin, Kasina Wielka, Tylicz, Binczarowa, Tylicz i Łukawica.

Współpraca pomiędzy księżmi a urzędnikami układala się dobrze. Władze kościclne szanowały władze konserwatorskie, choć zdarzały się wypadki niszczenia zabytków, jak np. w Tyliczu. Był to czas wielkich odkryć, do których można zaliczyć odkrycia polichromii z XIV wieku w Miechowie scena Ukrzyżowania z grupą z trzema Mariami - czy też malarskiej dekoracji renesansowej $w$ kościele $w$ Mogile $z$ około 1562 roku. Sa to oczywiście 
wybrane przyklady, oprócz nich odslonięto polichromie w Ruszczy, Raclawicach Olkuskich, Lipnicy Murowanej i Krościenku (z roku 1583 - dzielo Jakuba Koraba). Przeprowadzano niewiele gruntownych prac przy kościolach dlatego, że mimo wojny były w dość dobrym stanie. Przykładowo wykonano w tym czasie ze środków wlasnych remont północnej wieży gotyckiej z XV wieku kościola parafialnego w Nowym Sączu. Więcej robót wymagaly budowle drewniane. W latach 1952-1954 zostal odnowiony wylączony z kultu kościól drewniany $z$ okolo 1700 roku, dzielo cieśli Jana Chlipalskiego i Jędrzeja Topora w Bialce Tatrzańskiej. W kościele tym w 1970 roku, przy wspólpracy mieszkańców wsi i proboszcza oraz studentów Kola Naukowego Historii Sztuki Uniwersytetu Jagiellońskiego, jak również autora tej pracy, urządzono muzeum wnętrza. Prowadzono też prace $w$ kościele drewnianym $w$ Królówce kolo Bochni z roku 1563. Miało tam być urządzone, co bylo interesujacym choć niezbyt szczęśliwym rozwiązaniem, mauzoleum poety, krytyka i historyka Kazimierza Brodzińskiego (1791-1835).

Remontowano też kościól cmentarny w Lipnicy Murowanej koło Bochni.

Prace przy malarstwie sztalugowym laczyły się zarówno ze zlym zachowaniem zabytków, jak i odkryciami. Odnowiono gotycki obraz "Zdjęcie z krzyża" w Żywcu, pochodzący z tamtejszego kościoła parafialnego, później umieszczony $w$ zbiorach muzealnych.

Rewelacyjnym odkryciem było ustalenie, że skrzydła włączone $w$ barokowy oltarz w Barcicach koło Nowego Sącza, pochodzą z okresu późnego gotyku; pierwotne malowidla zostaly odsłonięte ze środków własnych parafii. Przekazane również zostaly do fachowej konserwacji gotyckie obrazy: cenny tryptyk z 1477 roku w kościele w Więcławicach oraz Zatorze.

Dziela rzemiosla artystycznego rzadko stanowily w tym okresie przedmiot badań konserwatorskich. Zrekonstruowano i poddano gruntownej konserwacji sarkofagi Katarzyny i Gabriela Tarnowskich odkryte przy konserwacji Kaplicy Batorego (Mariackiej) przy Katedrze na Wawelu. Zostal też odnowiony sarkofag Lubomirskiego w zamku w Nowym Wiśniczu. Wtedy jeszcze nie było wiadome, że dzieło to można lączyć ze złotnikiem Janem Krystianem Bierpfaffem. Miara odkryć w tym okresie (1950-1958) może być fakt, że zanotowano 18 nieznanych rzeźb gotyckich od roku okolo 1400 do XVI wieku. Niewiele mniej gotyckich i późnogotyckich zabytków rzeźby zinwentaryzowano na

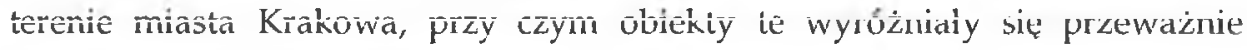
wyższym poziomem artystycznym niż znajdowane $w$ terenie.

Informacje przedstawione powyżej upoważniaja do następujacych wniosków: antykościelna, choć często zakamuflowana polityka wladz w latach 50-tych, gdy nie było jeszcze tak olbrzymich zniszczeń ekologicznych, nie wplywala negatywnie na działalność prac konserwatorskich. Przeciwnie, istniał zwrot ku sztuce, w tym kościelnej, który obrazował fakt, że w owym czasie rozpoczęło studia historii sztuki w Uniwersytecie Jagiellońskim 90-ciu adep- 
tów. Dobrze rozwijaly się techniki konserwatorskie. Brakowalo natomiast do 1956 roku kontaktów z ośrodkami zagranicznymi, co wyrażalo się między innymi brakiem zastosowania barwnych fotografii. Wskazać jednak trzeba na brak zainteresowania zabytkami $z$ drugiej połowy XIX wieku i pierwszej polowy $X X$ wieku (które często byly nieświadomie niszczone). Ale pewna winę ponosily tu programy studiów, które właściwie nie uwzględniały sztuki kościelnej XIX wieku i XX wieku. W sumie z wielu przyczyn, które trudno tu analizować, można powiedzicć, że w zakresie inwentaryzacji i ochrony zabytków po roku 1945 iv Polsce wcale nie bylo upadku. Jest to, a może raczej byl, zloty okres dla tych dziedzin.

Artykul niniejszy referowany byl w Papieskiej Akademii Teologicznej w Krakowie, Wydział Historii Kościola, na sesji naukowej: „Kościól katolicki w Europie Środkowej w dobie komunizmu".

R. Brykowski, Nieznane fragmenty polichromii to małopolskich kościołach, Biuletyn Historii Sztuki, R. 27:1965, nr 4.

M. Kornecki, Nieznane zabytki rzeźby gotyckiej w woj. krakowskim. "Wiadomości Konserwatorskie". 1958.

Tenże, Wojezuództwo krakowskie. Kronikn prac konserwatorskich. "Ochrona zabytków". R. 11:1958.

Tenże i J. Samek, Województwo krakowskie. Kronika prac konserwatorskich. "Ochrona zabytków". R. 7:1954.

W. Krassowski, Architektura drewniana wo Polsce, Warszawa 1961.

A. Kydryńska, O pracach konserwatorskich przy malowidłach ściemych w latach 1945-1957, Wiadomości Konserwatorskie, Kraków 1958.

H. Pieńkowska, Renesansowa polichromia w Modlnicy. "Zeszyty Naukowe UJ". Prace z Historii Sztuki, z. 21965.

H. Pieńkowska i T. Staich, Drogami skalnej zienii. Kraków 1958.

J. Samek, Kościót Śsw. Jana Chrzciciela wo Jerzmanowvicach. „Biuletyn Historii Sztuki”. R 20:1959, nr 2.

Tenże, Niezname fragmenty z wieku XIII w kościele Św. Janta w Krakowie. „Biuletyn Historii Sztuki". R. 21:1959, nr 3-4. 